\title{
THE MAJESTIC EQUALITY OF DISENFRANCHISEMENT: ASSESSING THE RIGHT TO FREEDOM FROM DISCRIMINATION IN LIGHT OF THE NGARONOA LITIGATION
}

\section{Charlie Cox*}

\begin{abstract}
The right to freedom from discrimination in New Zealand is underpinned by equality, one of the most influential, yet amorphous principles in political theory. This article argues that the failure of New Zealand courts to articulate the norms behind the anti-discrimination guarantee enables arbitrary and inconsistent reasoning. The decisions of the High Court in Taylor v Attorney-General and the Court of Appeal in Ngaronoa $\mathrm{v}$ Attorney-General thus reflect a wrong turn in New Zealand discrimination law, taken in the case of Ministry of Health $\mathrm{v}$ Atkinson. Because discrimination law necessitates moral judgment, this article argues that the courts have been wrong to treat discrimination law as a largely amoral enterprise. Seen in this context, it should be unsurprising that the decisions of Taylor v Attorney-General and Ngaronoa v Attorney-General appear to mask moral judgments behind a façade of empiricism and common sense, and reveal different conceptions of equality.
\end{abstract}

\section{INTRODUCTION}

[T]he majestic equality of the laws ... forbid[s] rich and poor alike to sleep under the bridges, to beg in the streets, and to steal their bread. ${ }^{1}$

The principle of equality rests at the heart of almost all contemporary liberal moral and political theories. $^{2}$ Unsurprisingly, equality has underpinned approaches to the right to be free from

* Submitted for the LLB (Honours) degree, Faculty of Law, Victoria University of Wellington. Recipient of the Robert Orr McGechan Memorial Prize for the Best Student Work for the Victoria University of Wellington Law Review. I am most grateful for the comments and patience of my supervisor, Professor Claudia Geiringer.

1 Anatole France The Red Lily (Winifred Stephens (translator), Dodd, Mead \& Co, New York, 1925) at 91.

2 Louis P Pojman and Robert Westmoreland (eds) Equality (Oxford University Press, New York, 1997) at 1. 
discrimination in the New Zealand Bill of Rights Act 1990 (the Bill of Rights). ${ }^{3}$ However, equality without more - is a fundamentally elusive concept. It must be imbued with some moral underpinning to exist beyond the abstract. ${ }^{4}$ Anti-discrimination norms, therefore, are of crucial importance to the resolution of the pressing social issues placed in front of judges. A failure to clearly confront such norms, this article argues, permits a judicial subjectivity which threatens New Zealand's commitment to the rule of law.

This article suggests that the approaches to the indirect discrimination issue in Taylor $v$ AttorneyGeneral $^{5}$ and Ngaronoa v Attorney-General ${ }^{6}$ (referenced together as "the Ngaronoa litigation") reflect a wrong turn taken in New Zealand anti-discrimination law. The test for discrimination, adopted in Ministry of Health $v$ Atkinson, ${ }^{7}$ provides little normative guidance to a court seeking to apply the principle of equality. The two decisions are thus emblematic of concerns that, without such guidance, results are left to turn on the individual morality of the reviewing judge.

In Part II, this article introduces the discrimination claim in the Ngaronoa litigation, which involved a claim that the blanket ban on prisoner voting is indirectly discriminatory. It compares the decision of Fogarty $\mathrm{J}$ in the High Court decision of Taylor with the decision on appeal in Ngaronoa.

Part III places the Ngaronoa litigation in the context of a confused approach to discrimination jurisprudence in New Zealand. It contends that the anti-discrimination guarantee cannot be understood without reference to the principle of equality which underlies it. It concludes that the failure of the Court in Atkinson to provide normative guidance as to the anti-discrimination guarantee enables decisions to turn on arbitrary, ad hoc reasoning.

Using Part III as a springboard, Part IV examines how these issues were borne out in the Ngaronoa litigation. It further considers how the result of the litigation might have differed if the courts adopted a different meaning of equality.

3 See Quilter v Attorney-General [1998] 1 NZLR 523 (CA) at 573 per Tipping J, as cited in Ministry of Health $v$ Atkinson [2012] NZCA 184, [2012] 3 NZLR 456 at [116]. Section 19(1) reads: "Everyone has the right to freedom from discrimination on the grounds of discrimination in the Human Rights Act 1993."

4 See Peter Westen "The Empty Idea of Equality" (1982) 95 Harv L Rev 537.

5 Taylor v Attorney-General [2016] NZHC 355, [2016] 3 NZLR 111.

6 Ngaronoa v Attorney-General [2017] NZCA 351, [2017] 3 NZLR 643. The Ngaronoa litigation progressed to the Supreme Court, but the Court declined leave to appeal the discrimination issue because it did not consider it the "right case" to address the "intersection" between "the issues of discrimination and Māori overrepresentation": see Ngaronoa v Attorney-General [2017] NZSC 183 at [2].

7 Atkinson, above n 3. 


\section{THE DISCRIMINATION CLAIM IN THE NGARONOA LITIGATION}

\section{A The Context}

The right to vote has long been recognised as a core prerogative in a free and democratic society, underpinning equality and sustaining consent to government. ${ }^{8}$ Indeed, in 2010, Simon Bridges MP leapt to the defence of the "precious right", for which millions of "men and women have shed blood and lost their lives". 9 This was in support of a Bill imposing a blanket disqualification on prisoners from voting. Since that Bill was enacted - as the Electoral (Disqualification of Sentenced Prisoners) Amendment Act 2010 (the Amendment Act) - the disenfranchisement of prisoners has caused heated debate, especially around election time. ${ }^{10}$

The Ngaronoa litigation fell amongst a series of claims seeking to challenge the Amendment Act. ${ }^{11} \mathrm{Mr}$ Arthur Taylor and the other applicants were in the custody of the Department of Corrections when the Amendment Act was enacted. ${ }^{12}$ They sought a declaration (among others) that the Amendment Act was unjustifiably inconsistent with the right to be free from discrimination on the grounds of race and ethnicity, ${ }^{13}$ recognised under s 19 of the Bill of Rights. ${ }^{14}$ The High Court and Court of Appeal both dismissed the claim. ${ }^{15}$

\section{$B$ The Legal Framework}

The particular claim in the Ngaronoa litigation was of indirect discrimination. ${ }^{16}$ Indirect discrimination occurs when a facially neutral policy has a disproportionate impact on a group or person because of a particular characteristic of that group or person that corresponds with a prohibited ground of discrimination. ${ }^{17}$

8 Taylor v Attorney-General [2017] NZCA 215, [2017] 3 NZLR 24 at [185].

9 (21 Apr 2010) 662 NZPD 10339.

10 See for example Daniel Botha "The prisoner voting ban is still a disgrace" (3 March 2019) The Spinoff $\langle$ https://thespinoff.co.nz>.

11 Taylor, above $\mathrm{n}$ 5, at [33].

12 At [1].

13 This article only examines race because it was the key ground argued before the Court of Appeal. See Ngaronoa, above $\mathrm{n}$ 6, at [115].

14 Taylor, above n 5, at [42].

15 Taylor, above n 5, at [152]; and Ngaronoa, above n 6, at [164].

16 Taylor, above n 5, at [128]; and Ngaronoa, above n 6, at [20].

17 Human Rights Act 1993, s 21; and Andrew Butler and Petra Butler The New Zealand Bill of Rights Act: A Commentary (2nd ed, LexisNexis, Wellington, 2015) at [17.12.1]. 
Theoretically, indirect discrimination can be on any ground if, in context, it is sufficiently connected to one of the listed prohibited grounds in the Human Rights Act $1993 .{ }^{18}$ The ground acts as a proxy for the protected ground. ${ }^{19}$ For example, imposing a minimum physical strength requirement for a job will not directly discriminate, because strength is not included in the list of prohibited grounds of discrimination. But since men are likely to be physically stronger than women, the requirement may amount to indirect discrimination, because it will exclude far more women than men. ${ }^{20}$

In the Ngaronoa litigation, the claimants argued that the Amendment Act disproportionately impacted on, and thus indirectly discriminated against, Māori "based on relative prison and minority populations". ${ }^{21}$ That is, because Māori are overrepresented in prison, blanket disenfranchisement adversely affects Māori more than it does other races.

Both Courts accepted the test for discrimination set out in Atkinson. ${ }^{22}$ This requires that the claimant experiences: ${ }^{23}$

(1) differential treatment on a prohibited ground with respect to a person or group in comparable circumstances; and

(2) the treatment results in a "material disadvantage".

For limb (1), both Courts affirmed comparator analysis as a helpful tool for determining the existence of differential treatment. ${ }^{24} \mathrm{~A}$ comparator is a person or group in comparable circumstances to the claimant but for their membership of a protected group. ${ }^{25}$ If there is differential treatment between the claimant and comparator, this suggests that the differential treatment was based on a prohibited ground. ${ }^{26}$

While neither Court in the Ngaronoa litigation engaged with the point, as the Court of Appeal clarified following the Atkinson decision in the case of Child Poverty Action Group Inc v Attorney-

18 Human Rights Act, s 21.

19 Tarunabh Khaitan A Theory of Discrimination Law (Oxford University Press, Oxford, 2015) at 74.

20 Selene Mize "Indirect Discrimination Reconsidered" [2007] NZ L Rev 27 at 28.

21 Taylor, above n 5, at [42].

22 Atkinson, above n 3, at [55].

23 At [55].

24 Taylor, above n 5, at [137]; and Ngaronoa, above n 6, at [121].

25 Child Poverty Action Group Inc (CPAG) v Attorney-General [2013] NZCA 402, [2013] 3 NZLR 729 [CPAG] at [52].

26 Asher Gabriel Emanuel "To Whom Will Ye Liken Me, and Make Me Equal? Reformulating the Role of the Comparator in the Identification of Discrimination" (2014) 45 VUWLR 1 at 2. 
General (CPAG), limb (1) also requires a "causative link" between the differential treatment and prohibited ground. ${ }^{27}$ This may require separate analysis in indirect discrimination claims. ${ }^{28}$

As Fogarty $\mathbf{J}$ noted in the High Court, formulations of the comparator are different in cases alleging indirect discrimination, where the focus is on "differential impact". ${ }^{29}$ As such, the choice of comparator must be group-based. ${ }^{30}$ Both groups will fall within a chosen "pool" of individuals to whom the facially neutral policy applies. ${ }^{31}$

Limb (2) of the Atkinson test requires a context-based assessment of whether the differential treatment results in a "material disadvantage" to the claimant group. ${ }^{32}$ In Atkinson, the Court approvingly cited the High Court decision in Child Poverty Action Group Inc v Attorney-General, which noted the need to filter out claims where differential treatment results in only "theoretical, innocuous or de minimus [sic] disadvantage", recognition of which might trivialise the right. ${ }^{33}$ In Atkinson, the Court of Appeal substituted the language of "real/more than trivial" with "material disadvantage", ${ }^{34}$ but noted there was no "substantive difference" in meaning. ${ }^{35}$

\section{The Reasoning of the High Court}

\section{Differential treatment}

When considering comparator groups for limb (1) of the Atkinson test, Fogarty J appeared to tacitly accept the Attorney-General's submission that a comparison between Māori prisoners and nonMāori generally would be inappropriate. ${ }^{36}$ The Attorney-General submitted that, while there was a correlation between Māori race and imprisonment, imprisonment was no "necessary extension" of Māori race. ${ }^{37}$ For Fogarty J, overrepresentation was a "happenstance" resulting from the "poverty and

$27 C P A G$, above n 25, at [52].

28 At [52].

29 Taylor, above n 5, at [140].

30 At [140].

31 Khaitan, above n 19 , at 75.

32 Atkinson, above n 3, at [109].

33 Child Poverty Action Group Inc v Attorney-General HC Wellington CIV-2009-404-273, 25 October 2011 at [83], as quoted in Atkinson, above n 3, at [106].

34 At [109].

35 At [136].

36 Taylor, above n 5, at [144].

37 At [144]. 
dysfunctional upbringings ... common to most prisoners of every race".${ }^{38}$ Because the adverse impact felt by Māori prisoners was not caused by their membership of a protected group, Māori prisoners and non-Māori generally were thus not properly comparable.

Because of his view that Māori prisoners and non-Māori generally were not properly comparable, Fogarty J examined two alternative comparator formulations: first, between Māori prisoners and nonMāori prisoners; ${ }^{39}$ and secondly, between prisoners generally and non-prisoners. ${ }^{40}$

As for the first comparator, which he accepted as the "natural" option, ${ }^{41}$ Fogarty J held that there was differential treatment. But for their disenfranchisement, Māori prisoners could, through the electoral option, opt to register as voters in marginal seats, and thus wielded more electoral power than non-Māori prisoners. ${ }^{42}$ Because the Amendment Act also took away this discretion, it treated Māori prisoners unequally with respect to their non-Māori counterparts.

In terms of the comparison between prisoners generally and non-prisoners, Fogarty $\mathrm{J}$ appeared to suggest that, because the Amendment Act disenfranchises all prisoners, there could be no differential treatment. Both Māori and non-Māori prisoners lose out with respect to non-prisoners. ${ }^{43}$ However, he did not make any formal determination on this point, preferring to move straight to the question of material disadvantage. ${ }^{44}$ For the sake of completeness, it is worth noting that acceptance of this comparison would depart from the conventional wisdom that the prohibited ground should form the only material difference between the comparator groups. ${ }^{45}$

\section{Material disadvantage}

Turning to limb (2) of the test, Fogarty J's analysis of material disadvantage was the same for both comparator formulations he accepted. The loss of discretion to choose between electorates did not constitute "even indirectly a racist distinction or any indirect degrading of M[ā] ori prisoners". ${ }^{46}$

\footnotetext{
38 At [147].

39 At [145].

40 At [148].

41 At [145].

42 At [145]

43 At [148].

44 At [150].

45 Emanuel, above n 26, at 2.

46 Taylor, above n 5, at [151]
} 


\section{The Reasoning of the Court of Appeal}

While ultimately upholding the High Court finding that there was no discrimination, the reasoning of the Court of Appeal differed substantially.

\section{Differential treatment}

The Court accepted two alternative comparators: one between Māori and non-Māori prisoners (as was accepted before the High Court) ${ }^{47}$ and one between the Māori voting community and the nonMāori voting community. ${ }^{48}$ The Court did not mention the comparisons between Māori prisoners and non-Māori generally or between prisoners generally and non-prisoners.

Unlike the High Court, the Court of Appeal held that there was no differential treatment between Māori and non-Māori prisoners because the blanket disqualification placed all prisoners on equal footing. The removal of the electoral option treated Māori prisoners equally to non-Māori prisoners: neither group could vote. Its only effect was to remove "a downstream choice" which non-Māori prisoners never had. ${ }^{49}$ This reflected the Court's view "that it is not necessarily discriminatory to indirectly neutralise a provision facilitating positive discrimination". ${ }^{50}$ The result was thus characterised as one of "exact equality". 51

The Court supported its finding that there was no differential treatment between Māori and nonMāori prisoners by referring to the floodgates which would be released in the alternative. ${ }^{52} \mathrm{~A}$ finding of differential treatment, the Court held, would be to expose the entire criminal justice system to claims by overrepresented groups. Such groups, like men, young persons and Māori are necessarily disproportionately affected by any prison policies which impact their basic freedoms, such as a measure restricting recreation time. ${ }^{53}$

The comparison between the Māori and non-Māori voting communities was viewed more favourably by the Court of Appeal. The Court held that there was "an indirect difference in treatment"

47 Ngaronoa, above n 6, at [132].

48 At [147].

49 At [140].

50 At [145].

51 At [140].

52 At [138].

53 At [138]. See also Selwyn Fraser "Māori qua what? A claimant-group analysis of Taylor v Attorney-General" [2017] NZ L Rev 31 at 55. 
between the two, because Māori are significantly more overrepresented in prison than other racial groups. 54

Confusingly, the Court did not invoke its floodgates concern in respect of this comparison. However, the concern that the entire criminal justice system might be exposed to a proliferation of claims appears to extend also to this comparator. It is perhaps owing to the view the Court took on material disadvantage on this comparator that its previous concerns about floodgates were excluded from the analysis.

\section{Material disadvantage}

There being no differential treatment with respect to the comparison between Māori and nonMāori prisoners, the Court did not find it necessary to consider material disadvantage.

In relation to the comparison between the Māori and non-Māori voting communities, the Court held that, because less than one per cent of either Māori or non-Māori were incarcerated at the time of its judgment, the impact was "so small" that there could be no material disadvantage suffered by the Māori voting community. 55

\section{DISCRIMINATION: AN "EMPTY" RIGHT?}

To understand the problem with the approach taken by the two Courts it is helpful to place the decisions in the wider context of the development of New Zealand discrimination law. This article suggests that each Court's approach reflects a wrong turn in New Zealand discrimination law taken in Atkinson. This wrong turn taken in Atkinson is best understood in the context of an ongoing debate about the constitutional legitimacy of, and philosophical underpinnings behind, the principle of equality.

The basic issue with Atkinson is the Court's attempt to create a test for discrimination which involves little or no moral judgment. But, if it is empowered by equality, discrimination is inherently normative. Thus, because the two limbs of the Atkinson test provide little guidance to the reviewing court, they permit largely uninterrogated and ad hoc moral determinations, which are often masked as empiricism and common sense.

\section{A Equality or Non-Discrimination?}

In s 19 of the Bill of Rights, the drafters deliberately omitted the language of "equality" found in other bills of rights, favouring the ostensibly simpler language of "freedom from discrimination" and

54 Ngaronoa, above n 6, at [147].

55 At [148]. 
a limited number of prohibited grounds of discrimination. ${ }^{56}$ However, although this omission limited the permitted bases for judicial intervention, it failed to address the drafters' underlying concern about involving judges in contestable policy terrain.

The drafters thought that the concept of equality was "elusive" and might lead the courts into the uncertainty of "substantive policy". ${ }^{57}$ To include equality would go against the assurances in the White Paper that, with few exceptions, the Bill of Rights "would not control matters of substance". 58 The decision to exclude equality thus reflected the process-based theory of constitutional legitimacy used by drafters to overcome the difficulties inherent in allowing judges - unelected officials - to unilaterally determine the application and scope of fundamental human rights. ${ }^{59}$

Granted, freedom from discrimination is not simply a repackaging of "equal[ity] before and under the law". ${ }^{60}$ Discrimination is about treatment. It is "action-regarding": ${ }^{61}$ not being (at least directly) concerned with the situation people end up in. Because of this, anti-discrimination legislation will struggle to tackle specific instances of discrimination-based inequality where general sources of inequality persist. ${ }^{62}$

Moreover, whilst governance necessitates making value judgments about the distribution of resources in society (and thus differential treatment), ${ }^{63}$ with the grounds of discrimination limited to those listed in the Human Rights Act, ${ }^{64}$ judges do not have "free ranging power to enforce the broad idea" of equality. ${ }^{65}$ Rather, interventions must be confined to "particular offensive grounds". ${ }^{66}$

56 Grant Huscroft "Freedom from Discrimination" in Paul Rishworth and others The New Zealand Bill of Rights (Oxford University Press, Auckland, 2003) 366 at 366.

57 See Geoffrey Palmer "A Bill of Rights for New Zealand: A White Paper" [1984-1985] I AJHR A6 at [10.81][10.82].

58 At [4.11].

59 See generally Claudia Geiringer and Paul Rishworth "Magna Carta's Legacy? Ideas of Liberty and Due Process in the New Zealand Bill of Rights Act" [2017] NZ L Rev 597.

60 See Canadian Charter of Rights and Freedoms, pt 1 of the Constitution Act 1982, being sch B to the Canada Act 1982 (UK), s 15(1).

61 Elisa Holmes "Anti-Discrimination Rights Without Equality" (2005) 68 MLR 175 at 182.

62 See generally Sian Elias "Equality Under Law" (2005) 13 Wai L Rev 1 at 3 and following. See also Anthony Lester "Equality and United Kingdom Law: Past, Present and Future" [2001] PL 77 at 83.

63 Peter Hogg Constitutional Law of Canada (looseleaf ed, Thomson Reuters) vol 2 at [55.6(b)].

64 Human Rights Act, s 21.

65 KJ Keith "A Bill of Rights for New Zealand? Judicial Review Versus Democracy" (1985) 11 NZULR 307 at 316.

66 At 316 . 
However, as will become clear, a prohibition against discrimination on a closed list of grounds does little to quell the underlying concern of the drafters about transferring policy-making powers to judges. Equality remains the empowering ideal behind s 19 of the Bill of Rights. The Court in Atkinson described the very purpose of the right as to "give substance to the principle of equality". ${ }^{67}$ As Grant Huscroft notes, in truth, s 19 "provides a vehicle for advancing many ... [equality-based] claims". ${ }^{6}$ While courts cannot "discover" new grounds of discrimination, they still must determine the substantive scope and application of discrimination as it relates to the listed grounds. ${ }^{69}$ An understanding of the concept of discrimination, therefore, must be grounded in an understanding of equality.

\section{B Formal or Substantive Equality?}

In discrimination-based literature, commentators frequently assert what is, in the author's view, a false dichotomy between "formal" and "substantive" equality. ${ }^{70}$ Relatedly, in Atkinson, the Court faced a difficult choice in defining the right to be free from discrimination. It could either do so neutrally, against the touchstone of mere differentiation; or it could "definitionally limit" the right, so that its violation would require differentiation involving prejudice, stereotyping or the perpetuation of historical disadvantage. ${ }^{71}$ In making this choice, although the Court rightly dismissed the diction of "formal" and "substantive" equality as unhelpful, ${ }^{72}$ it did so out of a misunderstanding of the distinction. What resulted was a normatively impoverished test for discrimination.

The concept of "formal equality" is frequently mentioned in parallel with the Aristotelian idea that "likes should be treated alike". ${ }^{73}$ This is conceived as "the process of equal treatment". ${ }^{74}$ It aligns with the basic instinct that fair treatment requires consistency. ${ }^{75}$ The literary trend is to reject formal

67 Quilter v Attorney-General, above n 3, at 573 per Tipping J, as quoted in Atkinson, above n 3, at [116].

68 Huscroft "Freedom from Discrimination", above n 56, at 367.

69 Keith, above n 65, at 315 .

70 See for example Pojman and Westmoreland, above n 2, at 2. See also Sandra Fredman Discrimination Law (2nd ed, Oxford University Press, Oxford, 2011) at 11-14.

71 Atkinson, above n 3, at [75]-[78].

72 At [142]

73 See Andrews v Law Society of British Columbia [1989] 1 SCR 143 at [27] per McIntyre J.

74 Hugh Collins and Tarunabh Khaitan "Indirect Discrimination Law: Controversies and Critical Questions" in Foundations of Indirect Discrimination Law (Hart Publishing, Oxford, 2018) 1 at 4.

75 Fredman, above n 70, at 8. 
equality in favour of substantive equality. ${ }^{76}$ Formal equality is seen as inadequate to capture indirect discrimination - where facially neutral treatment merely perpetuates disadvantage. ${ }^{77}$

In Andrews v Law Society of British Columbia ${ }^{78}$ the Canadian Supreme Court rejected a formal account of equality for the purposes of s 15(1) of the Canadian Charter of Rights and Freedoms, the counterpart to s $19 .{ }^{79}$ Justice McIntyre held that an approach based on whether people are "similarly situated" was "seriously deficient". ${ }^{80}$ In his view, the language of "without discrimination" in s 15(1) qualifies the right, implying a "substantive" approach that only prohibits differentiation involving "prejudice or disadvantage". ${ }^{81}$ Thus, differential treatment does not always violate the equality guarantee, whereas identical treatment may often result in serious inequality. ${ }^{82}$

The drafters of the Bill of Rights picked up on the formal/substantive distinction in the White Paper, substituting the language of "formality" with "neutrality" and "substantiveness" with "invidiousness". In their view, "discrimination" could either be understood in "an entirely neutral sense, synonymous with 'distinction"'; 83 or it could be understood in an "invidious sense", implying something "unjustified, unreasonable or irrelevant". ${ }^{84}$ However, they envisioned that either understanding would lead to the same results, because a general justification clause (now s 5 of the Bill of Rights) authorises reasonable limits on the right to be free from discrimination. ${ }^{85}$

The fallacy at the centre of this distinction is that the concept of formal equality is circular. As Peter Westen famously argued, equality - without more - is "empty", because the idea of treating likes alike necessitates making a moral judgment of likeness. ${ }^{86}$ Because "categories of morally alike

76 See generally Nicholas Mark Smith Basic Equality and Discrimination: Reconciling Theory and Law (Routledge, Abingdon-on-Thames (UK), 2011) at ch 8.

77 See for example Bob Hepple "The Aims of Equality Law" (2008) 61 CLP 1 at 4. See also Nicola Lacey "From Individual to Group" in Bob Hepple and Erika M Szyszczak (eds) Discrimination: The Limits of Law (Mansell Publishing, London, 1992) 99 at 101.

78 Andrews, above n 73, at [28].

79 At [28].

80 At [28].

81 At [43].

82 At [34].

83 Palmer, above n 57, at [10.78].

84 At [10.78].

85 At [10.78].

86 See Westen, above n 4. 
objects do not exist in nature; moral alikeness is established only when people define categories". ${ }^{87}$ Therefore, statements of equality must collapse into rights-based analysis, ${ }^{88}$ because saying that people are relevantly alike is to "articulate a moral standard of treatment". ${ }^{89}$ As Pojman and Westmoreland point out: ${ }^{90}$

Except with abstract ideas, such as numbers, there is no such thing as pure equality, equality per se ...

Two things A and B, if they are equal, are equal with respect to some specific property or properties. Two

trees are of equal height, two baseball players have equal batting averages, two workers produce widgets

at the same rate.

If formal equality is "empty", it can be moulded to fit any philosophy - depending on the norms used to gauge likeness. Consequently, the dichotomy between formal and substantive equality is false. Formal equality does not exist beyond the abstract until a moral standard of treatment is articulated, at which point it becomes substantive. It is up to the person (or court) applying the principle that "likes should be treated alike" to determine who is relevantly alike, according to their chosen moral metric. As Peter Hogg observes, formal equality is therefore quite capable of capturing claims of indirect discrimination - the claimant is arguing that unlike cases (for example, where one group suffers from historically-based disadvantage) are being treated alike by the apparently neutral law. ${ }^{91}$

\section{The Moral Underpinning of Ministry of Health v Atkinson}

In this context, it becomes clear that any conception of discrimination must be informed by background norms if it is to lead to coherent jurisprudence. It is unfortunate, therefore, that the current approach to s 19 in New Zealand essentially embodies a formal approach to discrimination. Because the Atkinson test itself is "devoid of any normative content", 92 its application acts as a vehicle for normative content. While fronting as a common sense and fact-based assessment, a moral undercurrent is necessary to inform both of its limbs.

To repeat, beyond the threshold question of material disadvantage, all that is required for the Atkinson test to be made out is differential treatment in comparable circumstances. ${ }^{93}$ Indeed, the Court expressly rejected the "invidious" or "substantive" approach proposed by the Ministry of Health. ${ }^{94}$

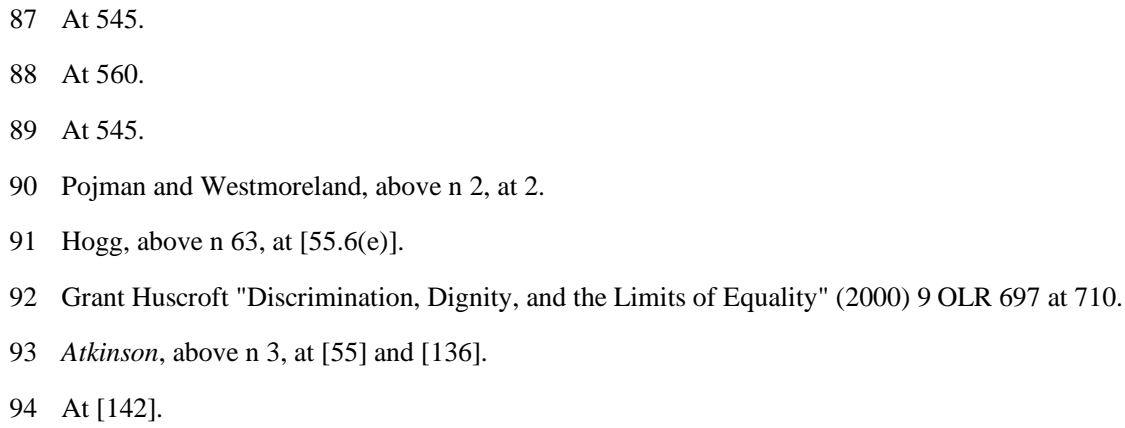


The test for s 19 is thus broadly analogous to the "similarly situated test" which was rejected in Andrews in favour of a substantive approach. ${ }^{95}$ This section will examine each limb of the Atkinson test in turn.

\section{Differential treatment and the role of the comparator}

Equality - and by extension, principles of non-discrimination - are frequently thought of as fundamentally comparative. ${ }^{96}$ As noted, a "comparator" is often used to establish that a claimant has suffered different treatment to another person or group in comparable circumstances. ${ }^{97}$ A person or group is treated unequally only if they are treated differentially from a comparator (whether real or hypothetical) that is considered relevantly alike to them.

However, the Court in Atkinson did not explain what might constitute "comparable circumstances", aside from noting that it was important to exclude from the formulation "contested assumptions"98 or the "philosophy which is said to be discriminatory". 99 This was despite its acknowledgement of the widespread difficulties associated with the test - which has been described in the United Kingdom as "arid and confusing". 100

The assumption underlying comparator-based reasoning is that once the discriminatory ground is discounted, treatment must be merit-based. ${ }^{101}$ Determinations as to the "appropriate" comparator, however, reflect the moral judgments necessary to give meaning to the principle of equality. As Goldberg observes, comparators act as an "empirical patina", which mask "the inevitable and contestable judgments about the qualities that make for an acceptable comparison, as well as the underlying normative judgments about the nature of discrimination". ${ }^{102}$

This masking effect is compounded by the difficulty of separating the identification and justification of discrimination. A finding of non-comparability risks assuming the validity of the

95 Andrews, above n 73, at [43].

96 Huscroft "Discrimination, Dignity, and the Limits of Equality", above n 92, at 697. But see Hannah Bain "Turning Equality into Fact: The Status of Comparator Group Analyses in New Zealand Discrimination Law" (LLB (Hons) Dissertation, Victoria University of Wellington, 2010) at 9.

97 Atkinson, above n 3, at [60].

98 Ministry of Health v Atkinson (2010) 9 HRNZ 47 (HC) at [92], as quoted in Atkinson, above n 3, at [67].

99 Atkinson, above n 3, at [67].

100 Shamoon v Chief Constable of the Royal Ulster Constabulary [2003] UKHL 11, [2003] 2 All ER 26 at [11] per Lord Nicholls.

101 Fredman, above n 70 , at 8 .

102 Suzanne B Goldberg "Discrimination by Comparison" (2010) 120 Yale LJ 728 at 740 (footnotes omitted) See also Emanuel, above n 26. 
rationale used to justify the differential treatment. As Clayton and Tomlinson note, the choice of comparator is therefore "notoriously slippery": 103

...there is no limit to the analogies or disanalogies which might be drawn between two groups or individuals. Furthermore ... the justification of discrimination will often depend on showing that the comparators are not, in truth, analogous.

The difficulty with defining discrimination against the touchstone of differentiation, as the Court did in Atkinson, is that it presupposes that justification is only relevant to s 5 of the Bill of Rights. ${ }^{104}$ As Huscroft notes, the approach effectively "ignor[es] the need to define the right and mov[es] directly to the question of justification". ${ }^{105}$ Analysis as to differentiation is not morally neutral, and often the identification and justification of discrimination will not be neatly separable. Therefore, the concern is not - as others have suggested - simply about expanding the scope of judicial review, or about trivialising the right. ${ }^{106}$ Rather, it is about judges inserting their own morality into the analysis such that the scope of judicial review expands and contracts relative to the individual judge.

It is for this reason that limiting judicial intervention to the grounds listed in the Human Rights Act does little to mitigate the Bill of Rights drafters' concerns about giving judges "broad and unconfined" powers to second-guess public policy. ${ }^{107}$ A court can pass off its comparator analysis as "a matter of logical deduction", ${ }^{108}$ replacing the need for further scrutiny. Where a court apprehends that a case is not properly described as discriminatory, or that there is an alternative, nondiscriminatory explanation for the differential treatment, it is free to conclude that the comparator suggested by the claimant is inappropriate. ${ }^{109}$

For a simple example of these issues, consider the case of British Columbia (Public Service Employee Relations Service) v British Columbia Government and Service Employees' Union (BCGSEU) (Meiorin). ${ }^{110}$ The claim challenged an aerobic standard required to become a forest firefighter which had the effect of excluding a disproportionate number of women compared to

103 Richard Clayton and Hugh Tomlinson The Law of Human Rights (2nd ed, Oxford University Press, New York, 2009) vol 1 at [17.138].

104 Huscroft "Discrimination, Dignity, and the Limits of Equality", above n 92, at 711.

105 At 710

106 At 711. See also Julia Adams "Breaking the Constitution: Discrimination Law, Judicial Overreach and Executive Backlash After Ministry of Health v Atkinson" [2016] NZ L Rev 255 at 267.

107 Keith, above n 65, at 315 .

108 Adams, above n 106, at 271.

109 See generally Emanuel, above n 26.

110 British Columbia (Public Service Employee Relations Commission) v British Columbia Government and Service Employees' Union [1999] 3 SCR 3 [Meiorin]. 
men. ${ }^{111}$ The rationale for the standard might be that the job entails a high degree of physical exertion. A reviewing court, in incorporating "the discriminatory circumstances" (the rationale for the differential treatment), ${ }^{112}$ might find no appropriate comparison to exist between men and women. This is because, assuming the validity of the policy, men and women are not relevantly alike, because men on average are physically stronger than women. In making this determination, the prima facie right (as embodied in the Atkinson test) takes on the work of justification. While this surely amounts to incorporating the discriminatory "philosophy" - which the Court in Atkinson warned against ${ }^{113}$ the blurred line between identification and justification of discrimination means that the solution in all cases is not so simple.

\section{Causation}

In cases of direct discrimination, if differential treatment can be seen through the lens of a mirror comparator (where the comparator group shares all the claimant group's characteristics bar its membership of a protected group), then the inference that the differential treatment was "on the grounds of discrimination" is strong. ${ }^{114}$ But as the Court of Appeal clarified in $C P A G$, the situation is different where the claim concerns the disproportionate effects of a facially neutral policy on a protected group (in the case of indirect discrimination). ${ }^{115}$ In such cases, the Court held, further analysis is necessary to establish causation between the differential treatment and the prohibited ground. ${ }^{116}$ As in other jurisdictions, the greater the disproportionate effects, the more likely the disparity between groups is non-random. ${ }^{117}$ But it remains to be established that any disparity is "real and not merely a coincidence". ${ }^{118}$ The Court in $C P A G$ considered this to be part of the first limb of the Atkinson test. ${ }^{119}$

Questions of causation may throw courts into uncertain moral territory and confront them with difficult sociological questions. To borrow an example given by Khaitan and Steel, consider a facially

111 Huscroft "Discrimination, Dignity, and the Limits of Equality", above n 92, at 711.

112 Karon Monaghan Equality Law (Oxford University Press, New York, 2007) at [6.39].

113 Atkinson, above n 3, at [67].

114 Emanuel, above n 26, at 22.

$115 C P A G$, above n 25, at [52].

116 At [52].

117 Tarunabh Khaitan and Sandy Steel "Wrongs, Group Disadvantage and the Legitimacy of Indirect Discrimination Law" in Hugh Collins and Tarunabh Khaitan (eds) Foundations of Indirect Discrimination Law (Hart Publishing, Oxford, 2018) 197 at 203.

118 Mize, above n 20, at 45.

$119 C P A G$, above n 25, at [52]. 
neutral psychometric test which must be passed for job eligibility. ${ }^{120}$ Black applicants are only 25 per cent as likely to pass the test as their white counterparts and the difference between the groups is statistically significant. It might be objected that the disparity results from black applicants being subject to higher levels of poverty and poorer education - and that the difference in outcomes is therefore, in the language of Fogarty J, "happenstance". ${ }^{121}$

The objection raised is akin to that of remoteness often encountered in tort law - the assumption being that race is not sufficiently connected to poverty or poorer education to warrant a finding of causation. But while poverty and poorer education are likely the more proximate causes of failure, "[t]hat does not mean that race cannot be located lower down the chain of causes". ${ }^{122}$ Indeed, the "impoverishing impact of salient characteristics such as race and caste is well-documented". ${ }^{123}$ The considerable disproportionate rate at which black candidates failed necessarily pulls toward the conclusion that race was a material causal factor.

Although it may be legitimate to conclude that there was no causal link between the differential treatment and a prohibited ground of discrimination, an intuitive assessment as to causation may again prompt a court to prematurely exclude viable claims through its choice of comparator. For example, if a court concluded that the disparate impact was a matter of chance, it could narrow the comparison to one between black applicants who were unable to pass the test and other applicants who were likewise unable to pass. Because each group is thus affected in an undifferentiated fashion (and indeed, members of each may be subject to similar levels of poverty and poor education), the disparate impact observed between black and white applicants as a whole is obscured, removing the need to proceed with the discrimination inquiry.

\section{3 "Material disadvantage"}

The central difficulty with the inquiry into material disadvantage is that no clear methodology has emerged. While disadvantage usually refers to "less favourable treatment", beyond this, little is clear. ${ }^{124}$ Responding to a submission that disadvantage defined by its degree "rather than by its nature is inherently arbitrary and provides no analytical tool to identify at what point a disadvantage amounts to discrimination", the Court in Atkinson responded simply that context would provide the answer. ${ }^{125}$ In context, the Court held, "several dollars on one side [of a certain sum of income missed out on each

120 Essop v Home Office [2017] UKSC 27, [2017] 1 WLR 1343, as cited in Khaitain and Steel, above n 117, at 202.

121 Taylor, above $\mathrm{n}$ 5, at [147].

122 Khaitain and Steel, above n 117, at 208

123 At 208

124 Butler and Butler, above n 17, at [17.14.1].

125 Atkinson, above n 3, at [126]. 
week] ... may well make a real difference to the claimant group". ${ }^{126}$ Where the precise threshold lies is for the reviewing court.

Passing off the question of material disadvantage as contextual and fact-based again permits normative judgments to hide behind a façade of empiricism. In determining what disadvantage reaches a threshold of materiality, the court must rely on background norms to inform its analysis. While intended to provide a "useful, simple and flexible analysis", ${ }^{127}$ the necessity to invoke morality to make the determination adds to concerns that the test permits arbitrary, ad hoc reasoning.

\section{UNEQUAL EQUALITY IN THE NGARONOA LITIGATION}

The above-mentioned normative deficiencies in the Atkinson test for discrimination enable a clearer picture of the discrimination issue in the Ngaronoa litigation. The empowering ideal behind s 19, equality, is empty. The Atkinson test provides little normative guidance to courts. The concern that judges are free to insert their own subjective understandings of equality is borne out in the Ngaronoa litigation in the two Courts' application of both limbs of the Atkinson test. This section will hone in on the instances where the Courts appeared to be passing moral judgment as to the meaning of equality (or masking such judgment behind common sense and empiricism). It will contend that, unsurprisingly, if a different conception of equality were adopted by the Courts, a different result may have followed.

\section{A Differential Treatment and Comparator Choice}

\section{Māori prisoners and non-Māori generally}

In the High Court, a purportedly neutral approach to causation was invoked to reject a comparison between Māori prisoners and non-Māori generally. Recall the Attorney-General's submission that, because imprisonment is not a "necessary extension" of Māori ethnicity, there was no relevant causation. ${ }^{128}$ While presented as neutral, Fogarty J's implicit acceptance of this reasoning (evident in his comments that Māori overrepresentation was "happenstance") allowed an intuitive determination as to causation to control his choice of comparator. ${ }^{129}$ A wider comparison between Māori prisoners and non-Māori generally was deemed inappropriate because there was no proximate connection between Māori race and imprisonment.

Such hasty causal analysis is far from neutral. It ignores important sociological research on the connection between race and crime. Of course, Māori race is not in itself criminogenic. Claims that

126 At [126].

127 Butler and Butler, above n 17, at [17.14.1].

128 Taylor, above n 5, at [144].

129 At [147]. 
characterise the entire Māori race as "criminally inclined" must be seen as blatantly racist. ${ }^{130}$ Rather, Fogarty J's comments appear to align with the view that Māori overrepresentation comes down to overexposure to social and economic deprivation. For instance, one influential Department of Corrections report noted that Māori overrepresentation was simply "what could be predicted given the combination of individuals' life experiences and circumstances, regardless of ethnicity". ${ }^{131}$ Thus, the report found that overrepresentation was not "a 'Māori' problem at all". 132

Granted, overrepresentation - and therefore disproportionate disenfranchisement - on its own is insufficient if it is not causally connected to a prohibited ground. ${ }^{133}$ What would have clarified the analysis, as Fraser notes, is an identification of the characteristic connected to the prohibited ground which is said to have caused the disproportionate impact - what he terms the "qua attribute". ${ }^{134}$ This enables a clearer picture of the causation between the prohibited ground and the differential treatment - in particular, whether the prohibited ground was an operative factor in, or "material" to, the treatment. ${ }^{135}$ An example he suggests is "Māori qua structurally discriminated against". ${ }^{136}$ Given that the legacy of colonisation and pursuant structural discrimination is specific to Māori, ${ }^{137}$ it is then possible to inquire whether the qua attribute was a "material ingredient" in the differential effects. ${ }^{138}$

Instead, by failing to engage in the causation analysis required, Fogarty $\mathrm{J}$ made an unjustified moral determination about the connection between race and crime. To write-off disparate outcomes as "happenstance" arguably embodies a kind of "colonial thinking, where the 'problem' or 'deficit' lies with Māori ... [which] ensures that the outcomes of non-Māori are never closely examined and Pākehā privilege [is] never exposed". ${ }^{139}$ An approach which fails to unpack the relationship between offending and the indicators which predispose an individual to such offending arguably "depoliticises"

130 Department of Corrections Over-representation of Māori in the criminal justice system: An exploratory report (September 2007) at 6.

131 At 38 .

132 At 38 .

133 Atkinson, above n 3, at [55].

134 Fraser, above n 53, at 55.

$135 C P A G$, above n 25, at [64].

136 Fraser, above n 53, at 52.

137 At 52 .

138 At 39.

139 Papaarangi Reid and Bridget Robson "Understanding Health Inequities" in Ricci Harris and Bridget Robson (eds) Hauora: Māori Standards of Health IV: A Study of the Years 2000-2005 (Te Rōpū Rangahau Hauora a Eru Pōmare, Wellington, 2007) 3 at 5. 
the problem by treating crime as the logical corollary of individual - rather than collective - failure. ${ }^{140}$ Granted, the difficulty is making a finding of causation where the chain has grown "long and cumbersome". ${ }^{141}$ But courts should not simply gloss over such important analysis.

A focus on exposure to general "risk factors" ignores the reasons underlying why Māori are overrepresented in those factors. If proper attention was given to causation, a different result may have followed. Because indirect discrimination focuses on disproportionate impact, it does not matter that some Māori individuals commit crimes for reasons unrelated to their race, or that other prisoners suffer high levels of poverty and disadvantage, if, for a sufficient number of Māori prisoners, race was a relevant factor in their incarceration. On this account, it follows that Māori and non-Māori prisoners were not properly comparable and two Courts erred by failing to consider the comparison between Māori prisoners and non-Māori generally.

Another explanation of Māori overrepresentation stresses the importance of cultural factors. ${ }^{142}$ These cultural factors explain why Māori are overrepresented in so-called "risk factors". On their own, risk factors ignore the reality that the forces which underpin Māori circumstances are unique to Māori. ${ }^{143}$ The conditions in which the "choice" to commit crime is made must be placed in proper historical context. Ani Mikaere argues, for example, the reason Māori exist in a place of relative disadvantage compared to their Pākehā counterparts is the enduring legacy of colonisation where the colonised is forced to conform to the image of the coloniser. ${ }^{144}$ Likewise, in the criminal justice system, the imported model of individual responsibility metes out culpability according to morally defective choice, rather than wider social and economic circumstance. ${ }^{145}$ Indeed, the colonial criminal justice system is in many ways inimical to tikanga Māori, with its individualist and punitive focus. ${ }^{146}$ Mason Durie points to a complex web of interaction between historical context and exposure to risk factors, where the forces of colonisation - and the resultant loss of land, language and tikanga - have

140 See generally Patricia J Williams The Alchemy of Race and Rights (Harvard University Press, Cambridge (Mass), 1991).

141 Fraser, above n 53, at 53.

142 Bronwyn Morrison Identifying and Responding to Bias in the Criminal Justice System: A Review of International and New Zealand Research (Ministry of Justice, November 2009) at 67.

143 Moana Jackson The Maori and the Criminal Justice System: A New Perspective: He Whaipaanga Hou-Part 2 (Department of Justice, November 1988) at 64.

144 Ani Mikaere Colonising Myths: Māori Realities - He Rukuruku Whakaaro (Huia Publishers and Te Takūpu, Te Wānanga o Raukawa, Wellington, 2011) at 101-104.

145 Department of Corrections, above n 130, at 38.

146 See Khylee Quince "Maori and the criminal justice system" in Julia Tolmie and Warren Brookbanks (eds) Criminal Justice in New Zealand (LexisNexis, Wellington, 2007) at [12.2]. 
shaped Māori identity. ${ }^{147} \mathrm{He}$ notes therefore, that while "incarceration is the most visible form of imprisonment, an equally pernicious type of imprisonment is to be found in lifestyles from which there is no escape". 148

Scholars have also pointed to bias within the criminal justice system as an important contributing factor to overrepresentation. ${ }^{149}$ For instance, the Department of Corrections identifies that "apprehension rates do not simply reflect actual offending behaviour of persons in the community". ${ }^{150}$ There is evidence that a greater proportion of Māori compared to members of other ethnicities receive short term imprisonment sentences rather than home detention. ${ }^{151}$ Of those who were sentenced to home detention for "very serious offences", 61.2 per cent were European, and a mere 19 per cent were Māori. ${ }^{152}$ Further, Māori are twice as likely as non-Māori to be denied parole and serve the duration of their sentence. ${ }^{153}$

Given the disproportionate rate at which Māori are imprisoned compared to other groups, it is very likely that race was a major contributing factor, although it can still be proven that the link is coincidental. ${ }^{154}$ The above-mentioned explanations for Māori overrepresentation, however, recognise race as a fundamental part of the explanation. As Khaitan and Steel observe, it is unclear why connection between disadvantage (such as poverty) and race is necessarily more remote than a person's dress or hairstyle and race. ${ }^{155}$ Arguably, the fact that disadvantage is associated with group membership is a requirement that a characteristic (shared by members of the group) needs to satisfy to justify its protected status in discrimination law. ${ }^{156}$

\section{Māori prisoners and non-Māori prisoners}

In the High Court, the consequence of failing to engage in a proper causation analysis was that a narrow comparison between Māori and non-Māori prisoners was the only one properly considered. An intuitive determination as to causation was thus allowed to dictate the analysis. Unfortunately, this

147 Mason Durie Ngā Tai Matatū: Tides of Māori Endurance (Oxford University Press, Melbourne, 2005) at 62. 148 At 62 .

149 Morrison, above n 142, at 97.

150 Department of Corrections, above n 130, at 17.

151 Ministry of Justice Home Detention: A review of the sentence of home detention 2007-2011 (October 2011) at 14.

152 At 23 .

153 Waitangi Tribunal He Aha I Pērā Ai? The Māori Prisoners' Voting Report (Wai 2870, 2019) at 20.

154 Mize, above n 20, at 45 .

155 Khaitan and Steel, above n 117, at 208.

156 See for example Khaitan, above n 19, ch 2. 
comparator choice (which was also considered by the Court of Appeal) essentially disregards the complainant's central complaint of disproportionality, rendering the claim of indirect discrimination meaningless. As Fraser observes, Māori prisoners are not disproportionately affected by the loss of the vote (leaving aside for now the Māori electoral option), because with the accent placed at the individual level, all prisoners "suffer the harm of disenfranchisement in an equal and undifferentiated manner". ${ }^{157}$ This analysis is echoed in the Court of Appeal's statement that "non-M[ā]ori prisoners are treated the same way as M[ā]ori prisoners. Neither can vote". 158

This comparator formulation is analogous to that mentioned above in relation to the psychometric test. In that example, comparing black applicants who fail the test with white applicants who fail the test is meaningless. 100 per cent of all individuals in the two groups are unable to pass - it does not matter that more black applicants than white applicants are unable to reach the standard, because the comparison is not between black and white applicants in general. But the fact that the harm of failure was suffered in the same way by the individuals who did not meet the standard is irrelevant to the question of whether the psychometric standard had an adverse impact on black applicants.

Aside from the issue of its narrow framing, it is interesting to compare Fogarty J's approach to this comparison to that of the Court of Appeal. The two Courts adopted opposing views of differential treatment, illustrating the tendency for courts to insert subjective norms into the otherwise "empty" concept of equality. As noted, Fogarty $\mathrm{J}$ accepted that there was differential treatment between Māori and non-Māori prisoners because Māori could, through the electoral option, opt to register as voters in marginal seats. ${ }^{159}$ Conversely, the Court of Appeal held that there was no differential treatment because the result of the Amendment Act was to situate Māori prisoners in a place of "exact equality" with non-Māori prisoners. ${ }^{160}$

Both decisions reflect different judgments about the normative content of equality. Assuming the Māori electoral option was rightly conceived of as "positive discrimination", ${ }^{161}$ the Courts missed an opportunity to clarify the complex relationship between affirmative action and equality. On Fogarty J's approach, affirmative action is a means of giving effect to equality. His approach appears to accord with a substantive approach to equality, and the view that "[e]qual consideration for all may demand very unequal treatment in favour of the disadvantaged." ${ }^{162}$ Conversely, Butler and Butler, adopting a neutral approach to discrimination, argue that affirmative action policies constitute differential

157 Fraser, above n 53, at 46.

158 Ngaronoa, above n 6, at [137].

159 Taylor, above n 5, at [145].

160 Ngaronoa, above n 6, at [140] (emphasis added).

161 At [145] (emphasis added).

162 Amartya Sen Inequality Re-examined (Harvard University Press, Cambridge (Mass), 1995) at 1. 
treatment. ${ }^{163}$ But given that the Court of Appeal did not wish to "exclude the possibility that the removal of positive benefits could be discriminatory", ${ }^{164}$ its position is unclear. It is unfortunate that it did not clearly articulate the norms it used to inform its position for the benefit of future cases.

\section{B Material Disadvantage}

The fear that the ostensibly simple and flexible threshold question of material disadvantage allows an insidious moral slip is also borne out in the two judgments. This perhaps could have been anticipated from the test itself. While a finding of material disadvantage may hinge on the degree of adverse impact, this must in turn hinge on some normative backing. If material disadvantage depends "on the context", ${ }^{165}$ it is difficult to see how morals cannot creep into the determination.

In the High Court, Fogarty $\mathbf{J}$ appeared to adopt an invidious approach to material disadvantage. The finding that Māori prisoners losing the right to vote in Māori electorates was not "even indirectly a racist distinction or any indirect degrading of Maori prisoners" 166 runs directly counter to the judicial direction given in Atkinson to relegate all matters of justification to the s 5 inquiry. ${ }^{167}$ His approach seems to resonate with the defendant's submission rejected in Atkinson that discrimination required "prejudice or stereotyping". ${ }^{68}$ It is unfortunate, therefore, that Fogarty $\mathrm{J}$ treated his analysis of material disadvantage as self-evident and did not elaborate. Certainly, Fogarty J's approach is categorically unlike a threshold question of triviality, where "several dollars on one side of the equation may well make a real difference to the claimant group". ${ }^{169}$

The Court of Appeal did not expressly disclaim Fogarty J's analysis in its assessment of material disadvantage with respect to the comparison between the Māori and non-Māori voting communities. ${ }^{170}$ Indeed, because the Court focused exclusively on the degree of the impact of the Amendment Act on "M[ā]ori as a group", it is difficult to establish a clear picture of the moral metric that the Court was using. ${ }^{171}$ This may be the result of following the direction to treat material disadvantage as an apparently non-moral threshold question of triviality. But it is clear, on further analysis, that the finding of no material disadvantage because less than one per cent of both Māori

163 See Butler and Butler, above n 17, at [17.19.5].

164 Ngaronoa, above n 6, at [145].

165 Atkinson, above n 3, at [126].

166 Taylor, above n 5, at [151].

167 Atkinson, above n 3, at [117].

168 At [76].

169 At [126]

170 See Ngaronoa, above n 6, at [148].

171 At [148]. 
and non-Māori are incarcerated ${ }^{172}$ permits again an insidious creep of morals. Determining whether something is trivial or not requires a moral judgment and the Court of Appeal's reasoning is no exception.

First, focusing exclusively on the proportion of the claimant group suffering the adverse impact means the result turns arbitrarily on the comparator groups selected, and glosses over the normative inquiry required. As the Court acknowledged in Meiorin, the size of the affected claimant group is readily manipulable, meaning "it is difficult to justify using it as the foundation of the entire analysis". ${ }^{173}$ The larger the comparator groups, the more likely the subset of the groups affected by the neutral policy falls under the Court of Appeal's arbitrary one per cent threshold. The manipulability of the comparator groups is apparent in the Ngaronoa litigation, in terms of the choice the courts faced between comparing imprisoned groups or entire voting communities, but the point becomes especially clear in the employment context already mentioned.

Consider again the example of Meiorin, where an aerobic standard excluded a disproportionate number of women compared to men from becoming a forest firefighter. ${ }^{174}$ It is unclear whether the comparator groups should be men and women generally, men and women eligible to apply for the job, or those men and women who apply for the job. On the Court of Appeal's account, the successful claim in Meiorin would have been different if the chosen pool was men and women generally, because the persons actually denied the ability to become firefighters make up far less than one per cent of either comparator group's population. But as the Supreme Court of Canada in that case observed, the argument that a neutral standard is not discriminatory because its adverse effects were felt only by a few individuals results from a "narrowly utilitarian perspective". ${ }^{175}$ This was especially so given the ease of manipulating the size of the group affected. ${ }^{176}$ Indeed, if the judicial trend is towards adopting a flexible approach to the choice of comparator groups, ${ }^{177}$ grounding material disadvantage solely on the statistical relationship between the size of the group affected and the claimant's group is incoherent.

Secondly, the analysis also ignores the nature of the disadvantage suffered, glossing over important normative analysis. For Mize, one aspect of the "significantly disproportionate negative effect" required for a successful indirect discrimination claim is that the negative effect is not

172 At [148].

173 Meiorin, above n 110, at [34].

174 Meiorin, above n 110.

175 At [32].

176 At [34].

177 See for example Atkinson, above n 3, at [60]; CPAG, above n 25, at [51]; and Ngaronoa, above n 6, at [121]. 
trivial. ${ }^{178}$ This mirrors the rationale underlying the material disadvantage inquiry mentioned in Atkinson, being to filter out claims that might trivialise the right. ${ }^{179}$ Mize gives an example: ${ }^{180}$

$\ldots$ if the uniforms at a workplace had buttons on the smaller sizes and zips on the larger sizes, and it took

a few seconds longer to do up the buttons, this could not satisfy the "effects" standard, even if the group of women mostly ended up with the buttons... [because] it would ... be trivial.

Even though indirect discrimination is group-based, that does not remove the need to consider the disadvantage suffered at the individual level. Presumably, such a consideration must be part of the context-based assessment as to whether disadvantage suffered by a collective reaches the threshold of materiality. Indeed, the Court of Appeal's approach is a direct affront to the flexibility which the question of material advantage was intended to provide. ${ }^{181}$

Regardless of the comparator group chosen, a more logical approach to material disadvantage would have examined the extent of disproportionality in outcome between comparator groups in light of the normative importance of the disadvantage suffered. If this were the view taken by the Court of Appeal in relation to the comparison between the Māori and non-Māori voting communities, a different result might also have followed. Largely the same analysis follows from the suggested comparison between Māori prisoners and non-Māori generally.

The Canadian case of Sauvé v Canada (Chief Electoral Officer) involved a challenge to a law which disenfranchised those serving two or more years in prison. ${ }^{182}$ Because the Court took the view that the law unjustifiably infringed s 3 of the Canadian Charter (the right to vote), it did not consider the second claim that it infringed the equality guarantee expressed in s 15 of the Charter. ${ }^{183}$ Relevantly, though, the majority observed that: ${ }^{184}$

To the extent that the disproportionate number of Aboriginal people in penitentiaries reflects factors such as higher rates of poverty and institutionalized alienation from mainstream society, penitentiary imprisonment may not be a fair or appropriate marker of the degree of individual culpability ... the fact that 1,837 Aboriginal people are disenfranchised by this law, while close to 600,000 are not directly affected, does not justify restricting the rights of those 1,837 individuals for reasons not demonstrably justified under the Charter...

178 Mize, above n 20, at 44

179 Atkinson, above n 3, at [106].

180 Mize, above n 20, at 46.

181 Atkinson, above n 3, at [131]

182 Sauvé v Canada (Chief Electoral Officer) 2002 SCC 68, [2002] 3 SCR 519 at [1] (citations omitted).

183 At [63].

184 At [60]. 
The materiality of disadvantage should not be left to turn on numbers without a consideration of what is actually taking place. At the individual level, Māori are losing the right to vote, a right "preservative of other basic civil and political rights". ${ }^{185}$ The loss is occurring disproportionately, and, for many, is the result of race or factors proximate to it. Responding to the Court of Appeal's finding on material disadvantage, the Waitangi Tribunal's recent Mãori Prisoners' Voting Report noted the Court did not have the benefit of evidence that Māori were 11.4 per cent more likely to be removed from the electoral roll than non-Māori. ${ }^{186}$ Conversely, before the legislative change, Māori were just twice as likely as non-Māori to be removed from the roll. ${ }^{187}$ Further, because Māori are more likely to be imprisoned for lower-end offending, Māori are removed from the electoral roll in higher numbers than non-Māori. ${ }^{188}$ And, as the Crown accepted before the Tribunal, although intended to temporarily suspend voting rights, the Amendment Act "actually operates as a de facto permanent disqualification, due to low rates of re-enrolment upon release". ${ }^{189}$

Further, the cumulative effects of the disenfranchisement provision should be considered. The Amendment Act has been in force now for over eight years. As McLeod notes, "individuals are not wholly autonomous beings who exist in a vacuum: they are also members of communities whose behaviour and attitudes influence those around them". ${ }^{190}$ Because of this, laws which impact on an individual's right to vote may further a narrative of alienation and disaffectedness already pressing on marginalised communities. Relatedly, in its recent report, the Waitangi Tribunal concluded that the Amendment Act had a "ripple effect" on the whānau and wider community of those disenfranchised, meaning the Crown's failure to encourage positive voting habits breached its duty of active protection. $^{191}$

Significant and sustained disenfranchisement impacts beyond what can be observed in the outcome of a particular election. If material disadvantage is properly conceived as a threshold question only, it is difficult to see how the Amendment Act does not reach the requisite threshold. By glossing over the disproportionality and focusing exclusively on the size of the affected group, the Court

185 Reynolds $v$ Sims 377 US 533 (1964) at 562

186 Waitangi Tribunal, above n 153, at 17.

187 At 17

188 At 20.

189 At 8 .

190 Aman McLeod, Ismail K White and Amelia R Gavin "The Locked Ballot Box: The Impact of State Criminal Disenfranchisement Laws on African American Voting Behavior and Implications for Reform" (2003) 11 Va J Soc Pol'y \& L 66 at 71

191 Waitangi Tribunal, above n 153, at 23. 
presented its analysis as impartial and fact-based. But its analysis was imbued with a subtle value base which ignored the unfortunate reality of racially disparate impact.

\section{CONCLUSION}

The concept of equality underlies human rights law itself: individuals should have rights because each individual matters equally. ${ }^{192}$ On Ronald Dworkin's famous formulation, for example, individuals have a right to equal concern and respect. ${ }^{193}$ However, as the Bill of Rights drafters rightly recognised, equality is elusive. ${ }^{194}$ It is for this reason that the principle claims such appeal across the political spectrum. ${ }^{195}$

To return to Westen's argument, equality must be given normative content before it has any practical utility. ${ }^{196}$ The issue with discrimination law in New Zealand, as reflected in the Ngaronoa litigation, is that the "equality" said to underpin the prohibition on discrimination has not yet been defined. Both limbs of the discrimination test in Atkinson necessitate value judgments about differentiation, causation and material disadvantage, which in turn reflect value judgments about the nature of equality. However, the Ngaronoa litigation illustrates a tendency for courts to hide such judgments behind a façade of empiricism and common sense.

A more coherent approach to discrimination jurisprudence would, in the author's view, involve a self-conscious focus on the values said to underpin the non-discrimination guarantee. With little such normative guidance available to reviewing courts, it is unsurprising that decisions continue to be reached which "accord with individual judges' sense of fairness". ${ }^{197}$

192 Huscroft "Freedom from Discrimination", above n 56, at 367.

193 Ronald Dworkin Taking Rights Seriously (Harvard University Press, Cambridge (Mass), 1977) at 179-183.

194 Palmer, above n 57, at [10.81].

195 Huscroft "Discrimination, Dignity, and the Limits of Equality", above n 92, at 697.

196 Westen, above $\mathrm{n}$ 4, at 547.

197 Huscroft "Discrimination, Dignity, and the Limits of Equality", above n 92, at 711. 